\title{
Effects of Pb Tailings Exudated Liquids Stress on Physiology of Six Kinds of Aquatic Plants
}

\author{
Yao $\mathrm{Na}$ \\ College of Life Sciences, Engineering Research Center of the Chinese Ministry of Educationfor \\ Bioreactor and Pharmaceutical Development, Jilin Agricultural University,130118
}

Key Words: Pb tailings, exudated liquids, aquatic plants

\begin{abstract}
Lead (Pb) is a necessary element for plant growth, and it is also one of the main heavy metals which pollute the environment. Lead ore mining fields, lead metallurgical plants, type printing factories and others are also the important sources of lead pollution. We take the selection of appropriate remediation plants as the purpose in the study. We select six kinds of aquatic plants with strong survivability and good ornamental performance to conduct the experiment, namely Iris pseudacorus L.,Sagittaria sagittifolia L., Eleocharis tuberosa S., Phragmites australis (Cav.) Trin.ex Steud, Typha orientalis Pres. and Hydrocotyle vulgaris L.. We study the effects of antioxidant enzymatic system, non-enzymatic system and other physiological indexes of six kinds of aquatic plants under $\mathrm{Pb}$ tailings exudated liquids(PbL) treatment. Thus, we hope that this study can provide some helps for the future in-depth study on aquatic plants remediation of the water body polluted by heavy metal.

With the development of our country's economy, more and more people begin to focus on the governance of polluted environment. What's more, with the progress of science and technology, the improvement of phytoremediation heavy metal polluted water technology brings the gospel to people. In recent decades, phytoremediation technology has aroused the researchers' extensive interests, and the scientists have carried out a lot of work on the screening aspect of tolerant plants. That is to say, in the seriously polluted water area we plant the aquatic plants with good tolerance and good ornamental nature. We reap plants immediately and make use of them again after they are mature. It not only purifies the water quality to play the plants' accumulation characteristics on heavy metals but also it has a certain ornamental effect. The important function of aquatic plants in the rivers and lakes ecosystem has been recognized and applied by the research scholars around the world.We take the selection of appropriate remediation plants as the purpose in the study. We select six kinds of aquatic plants with strong survivability and good ornamental performance to conduct the experiment, namely Iris pseudacorus L.,Sagittaria sagittifolia L., Eleocharis tuberosa S., Phragmites australis (Cav.) Trin.ex Steud, Typha orientalis Pres. and Hydrocotyle vulgaris L.. We study the effects of antioxidant enzymatic system, non-enzymatic system and other physiological indexes of six kinds of aquatic plants under $\mathrm{Pb}$ tailings exudated liquids( $\mathrm{PbL}$ ) treatment. Thus, we hope that this study can provide some helps for the future in-depth study on aquatic plants remediation of the water body polluted by heavy metal.
\end{abstract}

\section{Materials and Methods}

\subsection{Experimental Materials}

The supplied experimental plants include Iris pseudacorus L.,Sagittaria sagittifolia L., Phragmites australis (Cav.) Trin.ex Steud, Eleocharis tuberosa S., Typha orientalis Pres. and Hydrocotyle vulgaris L.

The supplied experimental solution is exudated liquids obtained from the abandoned tailings after precipitation in lead ore regions of Dexing City, Jiangxi province, namely $\mathrm{Pb}$ tailings exudated liquids(PbL).

\subsection{Experimental Methods \\ 1.2.1 Seedlings Cultivation and Pb Tailings Exudated Liquids Treatment}


We mainly adopt Han Yulin and other people's methods to treat the six kinds of plant seedlings. After we select the uniform seedlings to cultivate them for a week so as to restore their growths in 1/4 Hoagland nutrient(HN), we plant four seedlings respectively in plastic basin with the size of $10 \mathrm{~cm} \times 15 \mathrm{~cm}$ to conduct $\mathrm{Pb}$ tailings exudated liquids treatment. We conduct two treatments by setting 1/4 Hoagland nutrient(CK) in control group, and $\mathrm{Pb}$ tailings exudated liquids(PbL) in treatment group. We repeat each treatment for three times. We place the six kinds of plants in the laboratory facing the sun to let them grow with $25{ }^{\circ} \mathrm{C}$ average temperature and 35000Lux average light. In the treatment period according to the specific conditions we supply the six kinds of plants with a certain amount of water every morning and evening. After 77 days of treatment, we take samples to measure growth, $\mathrm{Pb}$ concentration and other indexes.

\subsubsection{Measurement of Plants Physiology Indexes}

We refer to Gu Xiaohan and other people's methods to measure all antioxidant enzymatic system, non-enzymatic system and other physiological indexes of five kinds of plants.

\subsection{Data Calculation and Statistical Analysis}

About calculation and analysis of experiment data, we adopt Excel 2003, WPS Office system and SPSS linear regression analysis software to conduct, and use the STST analysis software to do difference significance analysis on experimental data. When $\mathrm{P}<0.05$, there is significant difference.

\section{Results and Analysis}

\subsection{Effects of $\mathbf{P b}$ Tailings Exudated Liquids Stress on the Malondialdehyde of Six Kinds of Aquatic Plants}

Malondialdehyde(MDA) is one of membrane lipid peroxidation produces, and it is always studied as the index of membrane lipid peroxidation. Under the $\mathrm{Pb}$ tailings exudate liquids stress, above-ground part MDA content of Eleocharis tuberosa S. among the six kinds of plants is the highest, and above-ground part MDA content of Sagittaria sagittifolia L. Is the lowest. And the highest content is 5.5 times of the lowest content. It shows that above-ground part cell membrane lipid peroxidation degree of Eleocharis tuberosa S. is comparatively higher. Among the six kinds of plants, the above-ground part MDA content of Hydrocotyle vulgaris L. under PbL treatment is also higher, and it shows its integrity of cell membrane structure is poor. The above-ground and under-ground part MDA contents of the rest four kinds of plants under PbL treatment are all lower. It shows that the cell membrane lipid peroxidation degrees of Typha orientalis Pres., Phragmites australis (Cav.) Trin.ex Steud, Sagittaria sagittifolia L. and Iris pseudacorus L. are low, and the cell membrane structure has a certain integrity.

\subsection{Effects of Pb Tailings Exudated Liquids Stress on Cell Membrane Permeability of Six Kinds of Aquatic Plants}

Under PbL treatment, above-ground and under-ground part electrical conductivities of six kinds of aquatic plants are all higher than the control group. What's more, above-ground part electrical conductivity values of Phragmites australis (Cav.) Trin.ex Steud, Sagittaria sagittifolia L., Eleocharis tuberosa S. and Hydrocotyle vulgaris L. are smaller than under-ground part, and they are $98 \%, 86 \%, 67 \%$ and $82 \%$ of under-ground part respectively. The above-ground and under-ground part values of other two kinds of plants, Typha orientalis Pres. and Iris pseudacorus L. don't appear to be much different. However, leaf cell relative electric conductivity is one of the indexes to measure the relative penetrability of plasma membrane. The higher the conductivity value is, it shows that the greater of leaf cell membrane damage degree is. Therefore, $\mathrm{PbL}$ treatment with high concentration has bigger damages on the roots systems of aquatic plants. As far as the significant difference degree is concerned, the under-ground part electric conductivity values of Sagittaria sagittifolia L. and Hydrocotyle vulgaris L. have significant difference compared with the control group $(p<0.05)$, and above-ground and and under-ground part electric conductivity values of other two kinds of plants all don't have significant difference compared with the control group(p>0.05). 
There are two key enzymes in antioxidant enzyme system of plants, namely peroxidase (POD) and superoxyde dismutase (SOD). When the plants are in the adversity and get the heavy metal stress, the two kinds of enzymes have the crucial effect on the whole physiological and biochemical reactions of plants.

Under PbL treatment, the above-ground part POD activities of Iris pseudacorus L., Sagittaria sagittifolia L., Typha orientalis Pres. and Phragmites australis (Cav.) Trin.ex Steud is higher than the under-ground part. Among them, the above-ground part of Iris pseudacorus L. is $238 \%$ higher than the under-ground part, and the above-ground part of Sagittaria sagittifolia L. is $82 \%$ higher than the under-ground part, and the above-ground part of Typha orientalis Pres. is 53\% higher than the under-ground part, and the above-ground part of Phragmites australis (Cav.) Trin.ex Steud is 28\% higher than the under-ground part. It shows that under $\mathrm{Pb}$ liquids treatment with high concentration the above-ground part inducing ability of four kinds of plants is stronger than the under-ground part. The POD activity of Sagittaria sagittifolia L. is very obvious, especially the above-ground part $\mathrm{Pb}$ liquids treatment with high concentration reaches the significant level compared with the control group $(\mathrm{P}<0.05)$, and it increases by $27 \%$ compared with the control group. The above-ground and and under-ground part POD activities of Phragmites australis (Cav.) Trin.ex Steud of the plants expect for Phragmites australis (Cav.) Trin.ex Steud also increase significantly. It shows that $\mathrm{Pb}$ tailings exudated liquids stress on Sagittaria sagittifolia L. and Phragmites australis (Cav.) Trin.ex Steud have high POD inducing ability. The POD activities of other four kinds of plants also increase to a certain degree. It indicates indirectly that the strength of POD activity determines the degree of resistance to heavy metal $\mathrm{Pb}$ of the six kinds of aquatic plants.

Under the $\mathrm{Pb}$ tailings exudated liquids stress with high concentration, the above-ground part SOD activities of Iris pseudacorus L., Typha orientalis Pres., Sagittaria sagittifolia L. and Hydrocotyle vulgaris L. have significant difference compared with the control group $(p<0.05)$, and they are $211 \%, 166 \%, 126 \%$ and $125 \%$ of the control group respectively. Under the PbL treatment, expect the above-ground part SOD activities of Sagittaria sagittifolia L. and Eleocharis tuberosa S. are $127 \%$ and $171 \%$ higher than the control group, the above-ground part SOD activities of other four kinds of plants all don't have significant difference compared with the control group $(\mathrm{p}<0.05)$. What's more, PbL stress on the above-ground part SOD activities of Typha orientalis Pres., Sagittaria sagittifolia L. and Hydrocotyle vulgaris L. has the significant activation function. The above-ground part SOD activities of the three kinds of plants are 181\%, $113 \%$ and $62 \%$ higher than the under-ground part respectively. It indicates again that the $\mathrm{Pb}$ tailings exudated liquids stress on the above-ground part SOD activities of Typha orientalis Pres., Sagittaria sagittifolia L., Hydrocotyle vulgaris L., and Iris pseudacorus L. has stronger inducing ability. SOD plays the relatively positive role in the antioxidant aspects of the four kinds of aquatic plants seedlings.

\subsection{Effects of Pb Tailings Exudated Liquids Stress on the Ascorbic Acid of Six Kinds of Aquatic Plants}

Ascorbic acid(ASA) is always involved in the metabolism in plants. It is one of the basic antioxidants which protect the cells from free radical damage. Under $\mathrm{Pb}$ tailings exudated liquids stress, the under-ground part ascorbic acid contents of Eleocharis tuberosa S., Hydrocotyle vulgaris L., Sagittaria sagittifolia L. and Phragmites australis (Cav.) Trin.ex Steu among the six kinds of plants, are relatively higher, and they are $96 \%, 97 \%, 94 \%$ and $87 \%$ of the control group. The under-ground part ascorbic acid contents of Typha orientalis Pres. and Iris pseudacorus L. are 20\% and $43 \%$ lower than the control group, and they achieve the significant level $(\mathrm{P}<0.05)$. It indicates that ascorbic acid plays a very important role in antioxidant aspects of Eleocharis tuberosa S., Hydrocotyle vulgaris L., Sagittaria sagittifolia L. and Phragmites australis (Cav.) Trin.ex Steud.

\section{Discussion}

Heavy metal $\mathrm{Pb}$ is the metal elements which mainly exist in the tailings exudated liquids abandoned in Dexing region. Once too high lead content exists in the plants after $\mathrm{Pb}$ tailings exudated liquids treatment, it is likely to cause the plants to die. Due to the different own situations of six kinds of aquatic plants, in addition the relationship with the surrounding environment, the 
tolerance and the absorption accumulation ability to heavy metals will present the differences, and at this time we need to detect the commonly used five kinds of physiological indexes, such as malondiadehyde, relative electric conductivity, peroxidase, superoxide dismutase, and ascorbic acid. We use the numerical value to reflect six kinds of aquatic plants' tolerances on heavy metal $\mathrm{Pb}$.

The plant cell membrane system acts as the medium of exchanging and transferring the materials and information in intracellular area and extracellular area. Its integral degree is one of the indexes which is used to evaluate the environmental response of plants' tolerance to the stress. In this experiment, compared with the control group, above-ground and and under-ground part electrical conductivity contents of Hydrocotyle vulgaris L. and Sagittaria sagittifolia L. have more significant rise. The above-ground and and under-ground part electrical conductivity values of Hydrocotyle vulgaris L. are both the highest. The above-ground and and under-ground part cell membrane permeability indexes of other four kinds of plants both don't appear to be much different from the control group. It shows that about the effect of heavy metal the damage degree for cell membrane of $\mathrm{Pb}$ stress Hydrocotyle vulgaris L. is the largest.

There are two key enzymes in antioxidant enzyme system of plants, namely peroxidase and superoxyde dismutase. When the plants are in the adversity and get the heavy metal stress, the two kinds of enzymes can protect the plants organs from harm so as to enhance the tolerance of plants. The leaf cell relative electric conductivity is one of the indexes to measure the relative penetrability of plasma membrane. The above-ground and and under-ground part electrical conductivity values of Hydrocotyle vulgaris L. are both the highest. The higher the conductivity value is, it shows that the greater of leaf cell membrane damage degree is. Therefore, the damage degree for cell membrane of $\mathrm{Pb}$ stress Hydrocotyle vulgaris L. is the largest. The antioxidant enzyme SOD and POD inside the six kinds of plants can remove the free radicals to some extent, and play an important role in improving the stress resistance of plants, especially Sagittaria sagittifolia L.. Pb tailings exudate liquids stress on SOD and POD inside the plants has very strong inducing ability. The under-ground part MDA contents of Eleocharis tuberosa S. and Hydrocotyle vulgaris L. Are higher. It shows that the damage degree of biological membrane of these two kinds of plant cells is also larger. Among the six kinds of plants the ascorbic acid content of Typha orientalis Pres. gets the greatest effect from $\mathrm{PbL}$. Combined with the research results in the second chapter, we can see that among the six kinds of plantsSagittaria sagittifolia L., Phragmites australis (Cav.) Trin.ex Steud, Eleocharis tuberosa S. and Hydrocotyle vulgaris L. have relatively stronger tolerance to $\mathrm{Pb}$ tailings exudated liquids. However, Sagittaria sagittifolia L., Iris pseudacorus L. and Eleocharis tuberosa S. have stronger $\mathrm{Pb}$ accumulation ability. Even though $\mathrm{Pb}$ accumulation ability of Phragmites australis (Cav.) Trin.ex Steud is lower, it has high biomass. Therefore, the five kinds of plants can be used for the remediation of the water body polluted by $\mathrm{Pb}$ tailings.

\section{References}

[1] Diao Weiping, $\mathrm{Ni}$ Wuzhong, $\mathrm{Ni}$ Tianhua, etc. Ecological Effect and Prevention Countermeasures of Water Body with Heavy Metal Pollution[J]. Guangdong Trace Elements Science, 2003, 10(3): 1 5.

[2]Mukwaturi M, Lin C. Mobilization of Heavy Metals from Urban Contaminated Soils under Water Inundation Conditions [J]. Journal of Hazardous Materials, 2015, 285: 445 452.

[3]Ding Zili, Li Shuqian, and Zhou Xu. Research on Mechanism and Application of Phytoremediation Soil Heavy Metal Pollution[J]. Hubei Agricultural Sciences, 2014(23).

[4]Valipour A, Hamnabard N, Woo K S, Ahn Y H. Performance of High-rate Constructed Phytoremediation Process with Attached Growth for Domestic Wastewater Treatment: Effect of High TDS and Cu [J]. Journal of Environmental Management, 2014, 145:1 8.

[5]Jiang Chun, Jiang Weiwei, and Zhou Peng. Mechanism of Aquatic Plants Remediation Eutrophied Water Body [J]. Anhui Agricultural Sciences, 2014(35). 
[6]Han Y L, Huang S Z, Gu J G, et al. Tolerance and Accumulation of Lead by Species of Iris L. [J]. Ecotoxicology, 2008, (17):853 859. 